\title{
Associations of immunological features with COVID-19 severity: a systematic review and meta-analysis
}

Zhicheng Zhang ${ }^{1,2}$, Guo Ai ${ }^{3}$, Liping Chen ${ }^{1}$, Shunfang Liư ${ }^{4}$, Chen Gong ${ }^{4}$, Xiaodong Zhu ${ }^{5}$, Chunli Zhang ${ }^{6}$, Hua Qin ${ }^{1}$, Junhui $\mathrm{Hu}^{2^{*}}$ and Jinjin Huang ${ }^{7^{*}}$ (D)

\begin{abstract}
Background: COVID-19 has spread widely worldwide, causing millions of deaths. We aim to explore the association of immunological features with COVID-19 severity.

Methods: We conducted a meta-analysis to estimate mean difference (MD) of immune cells and cytokines levels with COVID-19 severity in PubMed, Web of Science, Scopus, the Cochrane Library and the grey literature.

Results: A total of 21 studies with 2033 COVID-19 patients were included. Compared with mild cases, severe cases showed significantly lower levels of immune cells including $\mathrm{CD}^{+} \mathrm{T}$ cell $\left(\times 10^{6}, \mathrm{MD},-413.87 ; 95 \% \mathrm{Cl},-611.39\right.$ to 216.34), CD4 ${ }^{+} \mathrm{T}$ cell $\left(\times 10^{6}, \mathrm{MD},-203.56 ; 95 \% \mathrm{Cl},-277.94\right.$ to -129.18$), \mathrm{CD}^{+} \mathrm{T}$ cell $\left(\times 10^{6}, \mathrm{MD},-128.88 ; 95 \% \mathrm{Cl},-\right.$ 163.97 to -93.79$)$, B cell $\left(\times 10^{6} / \mathrm{L} ; \mathrm{MD},-23.87 ; 95 \% \mathrm{Cl},-43.97\right.$ to -3.78$)$ and $\mathrm{NK}$ cell $\left(\times 10^{6} / \mathrm{L} ; \mathrm{MD},-57.12 ; 95 \% \mathrm{Cl}\right.$, 81.18 to -33.06$)$, and significantly higher levels of cytokines including TNF-a (pg/ml; MD, $0.34 ; 95 \% \mathrm{Cl}, 0.09$ to 0.59 ), IL-5 (pg/ml; MD, 14.2; 95\%Cl, 3.99 to 24.4), IL-6 (pg/ml; MD, 13.07; 95\%Cl, 9.80 to 16.35), and IL-10 (pg/ml; MD, 2.04; $95 \% \mathrm{Cl}, 1.32$ to 2.75$)$, and significantly higher levels of chemokines as MCP-1 (SMD, 3.41; 95\%Cl, 2.42 to 4.40$)$, IP-10 (SMD, 2.82; $95 \% \mathrm{Cl}, 1.20$ to 4.45) and eotaxin (SMD, 1.55; 95\%Cl, 0.05 to 3.05). However, no significant difference was found in other indicators such as Treg cell $\left(\times 10^{6}, \mathrm{MD},-0.13 ; 95 \% \mathrm{Cl},-1.40\right.$ to 1.14$), \mathrm{CD}^{+} / \mathrm{CD}^{+}$ratio $(\mathrm{MD}, 0.26$; 95\%Cl, -0.02 to 0.55$)$, IFN- $\gamma$ (pg/ml; MD, 0.26; 95\%Cl, -0.05 to 0.56), IL-2 (pg/ml; MD, 0.05; 95\%Cl, 0.49 to 0.60), IL4 (pg/ml; MD, $-0.03 ; 95 \% \mathrm{Cl},-0.68$ to 0.62$)$, GM-CSF (SMD, $0.44 ; 95 \% \mathrm{Cl},-0.46$ to 1.35), and RANTES (SMD, 0.94; $95 \% \mathrm{Cl},-2.88$ to 4.75$)$.

Conclusion: Our meta-analysis revealed significantly lower levels of immune cells $\left(C D 3^{+} T, C D 4^{+} T, C D 8^{+} T, B\right.$ and NK cells), higher levels of cytokines (TNF-a, IL-5, IL-6 and IL-10) and higher levels of chemokines (MCP-1, IP-10 and eotaxin) in severe cases in comparison to mild cases of COVID-19. Measurement of immunological features could help assess disease severity for effective triage of COVID-19 patients.
\end{abstract}

Keywords: COVID-19, Severity, Immune cells, Cytokines, Chemokines, meta-analysis

\footnotetext{
* Correspondence: junhuihu@mednet.ucla.edu; zczhang@tjh.jmu.edu.cn ${ }^{2}$ Department of Molecular and Medical Pharmacology, David Geffen School of Medicine, University of California, Los Angeles (UCLA), Los Angeles, USA ${ }^{7}$ Department of Hematology, Tongji Hospital, Tongji Medical College, Huazhong University of Science and Technology, Wuhan 430030, China Full list of author information is available at the end of the article
}

(c) The Author(s). 2021 Open Access This article is licensed under a Creative Commons Attribution 4.0 International License, which permits use, sharing, adaptation, distribution and reproduction in any medium or format, as long as you give appropriate credit to the original author(s) and the source, provide a link to the Creative Commons licence, and indicate if changes were made. The images or other third party material in this article are included in the article's Creative Commons licence, unless indicated otherwise in a credit line to the material. If material is not included in the article's Creative Commons licence and your intended use is not permitted by statutory regulation or exceeds the permitted use, you will need to obtain permission directly from the copyright holder. To view a copy of this licence, visit http://creativecommons.org/licenses/by/4.0/ The Creative Commons Public Domain Dedication waiver (http://creativecommons.org/publicdomain/zero/1.0/) applies to the data made available in this article, unless otherwise stated in a credit line to the data. 


\section{Background}

Coronavirus disease 2019 (COVID-19) was caused by severe acute respiratory syndrome coronavirus 2 (SARSCoV-2) infection, which has spread around the world [1]. Till September 09, 2020, the SARS-CoV-2 has infected over 27 million people and caused over 890,000 deaths [2]. The severity of COVID-19 may be strongly related to the immune status of patients, but this is poorly understood. Therefore, it is necessary to investigate the association of immunological features with COVID-19 severity, which may help identify immune markers for effective triage of COVID-19 patients.

Although some studies have focused on the association between immunologic features and COVID-19 severity, the conclusions remain controversial. Chen et al. found that the SARS-CoV-2 infection can decrease the counts of $\mathrm{T}$ lymphocytes, particularly $\mathrm{CD}^{+}$and $\mathrm{CD}^{+} \mathrm{T}$ cells [3]. Qin et al. showed that the cytokines of severe COVID-19 cases, such as tumor necrosis factor alpha (TNF- $\alpha$ ), interleukin-5 (IL-5), IL-6 and IL-10, increased during the COVID-19 progression [4]. Sophie et al. demonstrated that the increased serum concentrations of IFN- $\gamma$ inducible protein-10 (IP-10) and granulocyte-macrophage colony-stimulating factor (GM-CSF) were associated with day-28 mortality of COVID-19 patients [5]. However, other studies have revealed that $\mathrm{CD}^{+}$and $\mathrm{CD}^{+} \mathrm{T}$ cells [4], some cytokines (IL5, IL-6 and IL-10) [6] and chemokines (GM-CSF and IP10) [7] showed no significant differences between severe cases and mild cases. Thus, we presented a meta-analysis of 21 studies in order to assess the association between immune cells $\left(\mathrm{CD}^{+} \mathrm{T}, \mathrm{CD}^{+} \mathrm{T}, \mathrm{CD}^{+} \mathrm{T}\right.$, Treg, $\mathrm{B}$ and NK cells), cytokines (TNF- $\alpha$, IFN- $\gamma$, IL-2, IL-4, IL-5, IL-6 and IL-10), chemokines (GM-CSF, RANTES, MCP-1, IP-10 and eotaxin) and COVID-19 severity respectively.

\section{Methods}

\section{Search strategy}

We performed a systematic literature search to identify relevant studies published up to September 09, 2020 in PubMed, Web of Science, Scopus, the Cochrane Library and the grey literature. The following combined search terms were used: ("Novel coronavirus" OR "Coronavirus disease 2019" OR "Coronavirus 2019" OR "nCoV-2019" OR “2019-nCoV” OR “COVID-19” OR "SARS-CoV-2”) and (("CD3 ${ }^{+} \mathrm{T}$ " OR "CD4 ${ }^{+} \mathrm{T}$ " OR "CD8 ${ }^{+} \mathrm{T}$ " $\mathrm{OR}$ "CD4 $4^{+} /$ CD8 ${ }^{+}$" OR "Treg” OR "B cell” OR "NK cell”) OR ("interferon gamma" OR "tumor necrosis factor alpha" OR "IL2" OR “IL-4" OR "IL-5” OR "IL-6” OR "IL-10") OR ("chemokine" OR "chemokines" OR "RANTES" OR “GM-CSF” OR “Eotaxin” OR “MCP-1” OR “IP-10”)).

\section{Study selection}

Inclusion criteria of the study were as follows: 1) studies with data on immune cells $\left(\mathrm{CD}^{+} \mathrm{T}, \mathrm{CD}^{+} \mathrm{T}, \mathrm{CD}^{+} \mathrm{T}\right.$,
$\mathrm{CD}^{+} / \mathrm{CD}^{+}$, Treg, $\mathrm{B}$ and NK cells), cytokines (IFN, TNF- $\alpha$, IL-2, IL-4, IL-5, IL-6 and IL-10) and chemokines (GM-CSF, RANTES, MCP-1, IP-10 and eotaxin) with mean \pm standard deviation (SD) or median (interquartile range, IQR); 2) patients could be grouped into severe cases and mild cases; and 3) studies with clear information on COVID-19 confirmation and included patients. The exclusion criteria were as follows: 1) studies without corresponding outcome of indicators; 2) studies without available full texts; 3) studies not published in English; 4) lack of mean \pm SD or mean (IQR) of indicators; 5) reviews, editorials, case reports, and meta-analyses.

Two investigators developed the search strategy and one investigator conducted the primary systematic search for all studies meeting the predetermined inclusion criteria. The titles and abstracts of the retrieved articles were screened for duplication and relevance to the topic. A second investigator assessed study eligibility, quality assessment, and data extraction, for validity and consistency. Full-text reports of the identified citations were reviewed by both the primary and secondary investigators in order to select the final studies. All discrepancies were resolved by consensus, and if necessary, by consultation with the third investigator.

\section{Data extraction}

The following data were extracted from each study: 1) the first author and year of publication; 2) study design; 3 ) the country where the study was conducted; 4) age; 5) sample size; 6) sex; 7) the levels of immune cells (CD4 ${ }^{+}$ $\mathrm{T}, \mathrm{CD}^{+} \mathrm{T}, \mathrm{CD}^{+} \mathrm{T}, \mathrm{CD} 4^{+} / \mathrm{CD}^{+}$, Treg, $\mathrm{B}$ and NK cells), and cytokines (IFN, TNF- $\alpha$, IL-2, IL-4, IL-5, IL-6 and IL-10), and chemokines (GM-CSF, RANTES, MCP-1, IP-10 and eotaxin). Median (IQR) values were converted to mean \pm SD using mathematical formulas as reported by Hozo et al. [8].

\section{Quality assessment}

Quality assessments of the studies were carried out based on the Newcastle-Ottawa Scale (NOS). The total NOS score $\geq 7$ indicated a good research quality of the included study.

\section{Data synthesis and analysis}

Data entry and analysis were performed with Review Manager 5.3 (The Cochrane Collaboration, Oxford, England). Heterogeneity within each group of studies was assessed by $\mathrm{Q}$ test and $I^{2}$ statistics. A random-effects model was used when $I^{2}>50 \%$ or $p<0.05$ and a fixedeffects model was used when $I^{2} \leq 50 \%$ or $p \geq 0.05$. For the continuous data, we calculated mean differences (MD) and 95\% confidence intervals (CI) between severe cases and mild cases. To investigate the potential publication bias, we visually examined the funnel plots. To 
assess the robustness of the results, we performed sensitivity analyses by removing one study at a time.

\section{Results}

Search results and characteristics of included studies

Figure 1 provides the flow diagram for study selection. Based on the inclusion criteria, 75 full articles were retrieved and 21 of these were included in the final metaanalysis. Duplicate publications, reviews, editorials, case reports, and studies without medians (IQR) and mean \pm SD of indicators were excluded. Table 1 presents the characteristics of the 21 included studies, with 758 severe cases and 1275 mild cases of COVID-19. All but one prospective study [9] of the studies included in this meta-analysis were retrospective studies, which were mostly performed in China. All studies were deemed of high quality with NOS scores at 7 or above. Details can be found in Table 2 .

\section{Associations of immune cells with COVID-19 severity}

Compared with mild cases, severe cases showed significantly lower levels of immune cells as $\mathrm{CD}^{+} \mathrm{T}$ cell $(\times$ $10^{6}, \mathrm{MD},-413.87 ; 95 \% \mathrm{CI},-611.39$ to $-216.34 ; I^{2}$, $100 \% ; p<0.001$, Fig. 2 a) with specifically $\mathrm{CD}^{+} \mathrm{T}$ cell $\left(\times 10^{6}, \mathrm{MD},-203.56 ; 95 \% \mathrm{CI},-277.94\right.$ to $-129.18 ; I^{2}$,
99\%; $p<0.001$, Fig. 2b) and $\mathrm{CD}^{+} \mathrm{T}$ cell $\left(\times 10^{6}, \mathrm{MD},-\right.$ 128.88; $95 \% \mathrm{CI},-163.97$ to $-93.79 ; I^{2}, 99 \% ; p<0.001$, Fig. 2 c), B cell $\left(\times 10^{6} / \mathrm{L} ; \mathrm{MD},-23.87 ; 95 \% \mathrm{CI},-43.97\right.$ to $-3.78 ; I^{2}, 87 \% ; p<0.001$, Fig. $\left.2 \mathrm{f}\right)$, and NK cell $\left(\times 10^{6} / \mathrm{L}\right.$; MD, -57.12 ; $95 \% \mathrm{CI},-81.18$ to $-33.06 ; I^{2}, 92 \% ; p<$ 0.001 , Fig. $2 \mathrm{~g}$ ). However, no significant difference was found in the other indicators as $\mathrm{CD} 4^{+} / \mathrm{CD}^{+}$ratio (MD, 0.26; $95 \% \mathrm{CI},-0.02$ to $0.55 ; I^{2}, 97 \% ; p<0.001$, Fig. $2 \mathrm{~d}$ ) and Treg cell $\left(\times 10^{6}, \mathrm{MD},-0.13\right.$; $95 \% \mathrm{CI},-1.40$ to 1.14 ; $I^{2}, 90 \% ; p=0.002$, Fig. 2e).

\section{Associations of cytokines with COVID-19 severity}

Compared with mild cases, severe cases showed significantly higher levels of cytokines including TNF- $\alpha$ (pg/ $\mathrm{ml}$; MD, 0.34 ; $95 \% \mathrm{CI}, 0.09$ to $0.59 ; I^{2}, 98 \% ; p<0.001$, Fig. 2h), IL-5 (pg/ml; MD, 14.20; 95\%CI, 3.99 to $24.4 ; I^{2}$, 99\%; $p<0.001$, Fig. 2l), IL-6 (pg/ml; MD, 13.07; 95\%CI, 9.80 to $16.35 ; I^{2}, 100 \% ; p<0.001$, Fig. $2 \mathrm{~m}$ ), and IL-10 (pg/ml; MD, 2.04; 95\%CI, 1.32 to $2.75 ; I^{2}, 99 \% ; p<$ 0.001, Fig. 2n). However, no significant difference was found in the other cytokines as IFN- $\gamma(\mathrm{pg} / \mathrm{ml}$; MD, 0.26; $95 \% \mathrm{CI},-0.05$ to $0.56 ; I^{2}, 98 \% ; p<0.001$, Fig. $\left.2 \mathrm{i}\right), \mathrm{IL}-2$ (pg/ml; MD, 0.05 ; $95 \% \mathrm{CI},-0.49$ to $0.6 ; I^{2}, 100 \% ; p<$ 0.001 , Fig. $2 \mathrm{j})$, and IL-4 (pg/ml; MD, $-0.03 ; 95 \% \mathrm{CI}$, 0.68 to $0.62 ; I^{2}, 100 \% ; p<0.001$, Fig. $2 \mathrm{k}$ ).

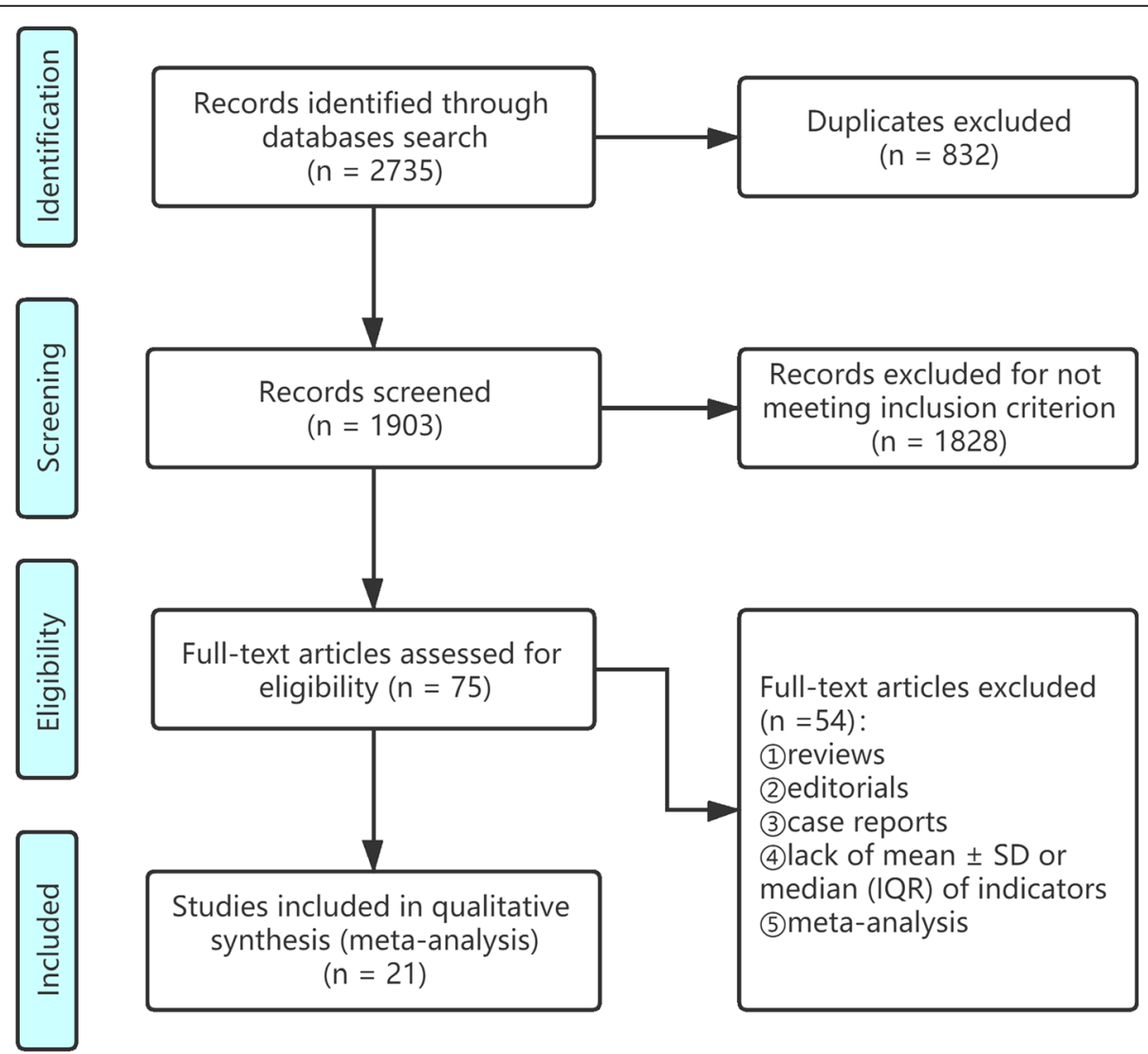

Fig. 1 Flow diagram for studies selection 
Table 1 Characteristics of studies included in the meta-analysis

\begin{tabular}{|c|c|c|c|c|c|c|c|}
\hline Author & Study Design & Country & Age (years) & Sample size (Severe) & Sample size (Mild) & Sample size & Sex (male \%) \\
\hline Chen G. 2020 [3] & Retrospective & China & $56(50-65)$ & 11 & 10 & 21 & $17(81 \%)$ \\
\hline Chen R. 2020 [31] & Retrospective & China & $56 \pm 15$ & 155 & 345 & 500 & $313(57.1 \%)$ \\
\hline Chi Y. 2020 [10] & Retrospective & China & 46 & 8 & 22 & 30 & / \\
\hline Du R. 2020 [9] & Prospective & China & $69 \pm 8$ & 21 & 42 & 63 & $30(47.6 \%)$ \\
\hline He R. 2020 [6] & Retrospective & China & $49(34-62)$ & 69 & 135 & 204 & 79 (38.7\%) \\
\hline Jiang M. 2020 [12] & Retrospective & China & $46(17-88)$ & 17 & 86 & 103 & $58(56.3 \%)$ \\
\hline Li S. 2020 [24] & Retrospective & China & 46 & 26 & 43 & 69 & $40(60.0 \%)$ \\
\hline Liu Y. 2020 [32] & Retrospective & China & / & 30 & 46 & 76 & / \\
\hline Ma J. 2020 [33] & Retrospective & China & $62(59-70)$ & 17 & 20 & 37 & $20(54 \%)$ \\
\hline Pallotto C. 2020 [34] & Retrospective & Italy & 65 & 13 & 25 & 38 & 19 (50.0\%) \\
\hline Qin C. 2020 [4] & Retrospective & China & $58(47-67)$ & 27 & 17 & 44 & $235(52 \%)$ \\
\hline Sophie H. 2020 [5] & Retrospective & France & 66 & 38 & 36 & 74 & 60 (81.1\%) \\
\hline Sun D. 2020 [15] & Retrospective & China & 65 & 11 & 25 & 36 & 29 (80.5\%) \\
\hline Urra J.M. 2020 [35] & Retrospective & Spain & 59 & 27 & 145 & 172 & $104(60.5 \%)$ \\
\hline Wan S. 2020 [13] & Retrospective & China & 46 & 21 & 102 & 123 & $66(53.7 \%)$ \\
\hline Wang F. 2020 [18] & Retrospective & China & $69 \pm 9$ & 14 & 14 & 28 & $21(75 \%)$ \\
\hline Zhang J. 2020 [19] & Retrospective & China & $38(32-57)$ & 93 & 18 & 111 & $46(41.4 \%)$ \\
\hline Zhao Y. 2020 [7] & Retrospective & China & 48 & 18 & 53 & 71 & $30(42.3 \%)$ \\
\hline Zheng Y. 2020 [36] & Retrospective & China & 49 & 26 & 63 & 89 & / \\
\hline Zhou Y. 2020 [14] & Retrospective & China & 42 & 5 & 12 & 17 & $6(35.3 \%)$ \\
\hline Zhu Z. 2020 [16] & Retrospective & China & 51 & 111 & 16 & 127 & 45 (35.4\%) \\
\hline
\end{tabular}

Age is described as mean or mean \pm SD or median (IQR)

\section{Associations of chemokines with COVID-19 severity}

Compared with mild cases, severe cases showed significantly higher levels of chemokines including MCP-1 (SMD, 3.41; 95\%CI, 2.42 to $4.40 ; I^{2}, 71 \% ; p=0.03$, Fig. 2q), IP-10 (SMD, 2.82; 95\%CI, 1.20 to $4.45 ; I^{2}, 91 \%$; $p<$ 0.001 , Fig. 2r), and eotaxin (SMD, 1.55; 95\%CI, 0.05 to $3.05 ; I^{2}, 87 \% ; p=0.01$, Fig. 2s). However, there was no significant difference in the other chemokines as GMCSF (SMD, 0.44; 95\%CI, -0.46 to $1.35 ; I^{2}, 85 \% ; p=$ 0.001, Fig. 2o) and RANTES (SMD, 0.94; 95\%CI, -2.88 to $4.75 ; I^{2}, 98 \% ; p<0.001$, Fig. 2 p).

\section{Sensitivity analysis}

Significant heterogeneity was identified across all the comparisons (Fig. 2). Sensitivity analyses showed that our results were not obviously impacted by exclusion to any specific study for " $\mathrm{CD} 3^{+} \mathrm{T}$ ", "CD4 $4^{+} \mathrm{T}$ ", "CD8 ${ }^{+} \mathrm{T}$ ", "CD4 $4^{+} / \mathrm{CD}^{+}$", "Treg", "B cell", "NK cell", "TNF- $\alpha$ " "IFN", "IL-2", "IL-4", "IL-5", "IL-6", "IL-10", "RANTES", "MCP-1", "IP-10" and "eotaxin" between the severe group and the mild group. After excluding the study Chi et al. [10] on GM-CSF (SMD, 0.94; 95\%CI, 0.58 to1.31), the sensitivity findings showed that there was a significant difference between pre- and post-sensitivity pooled SMDs, suggesting that it is better to keep this result in the meta-analysis. As such, our sensitivity analysis indicates that most of our results are reliable.

\section{Publication bias}

We assessed the publication bias of the literature by means of the funnel plots in all included studies of each indicator. Funnel plot analysis did not detect obvious publication bias as the shape of all funnel plots did not reveal any evidence of obvious asymmetry (Fig. 3).

\section{Discussion}

It is necessary to investigate the host immune response to SARS-CoV-2, which may help identify immune markers of disease severity for effective triage of COVID-19 patients [11]. Our study compared the levels of immune cells, cytokines and chemokines between mild and severe COVID-19 patients.

The variations of immune cell levels are inconsistent among different reports. The majority of our included studies reported significantly lower levels of immune cells $\left(\mathrm{CD}^{+} \mathrm{T}, \mathrm{CD}^{+} \mathrm{T}, \mathrm{CD} 4^{+} \mathrm{T}, \mathrm{B}\right.$ and NK cells) in severe cases compared with mild cases [3, 12, 13]. Only two studies didn't find significant reductions in $\mathrm{CD}^{+} \mathrm{T}$ cells $[4,14]$, while one study reported an increase of $B$ cell [15] in severe cases. Using all the collected evidence, 
Table 2 Newcastle-Ottawa Scale (NOS)

\begin{tabular}{|c|c|c|c|c|c|c|c|c|c|}
\hline $\begin{array}{l}\text { Included } \\
\text { studies }\end{array}$ & $\begin{array}{l}\text { Is the } \\
\text { definition } \\
\text { adequate? }\end{array}$ & $\begin{array}{l}\text { Represent } \\
\text { activeness of } \\
\text { the cases }\end{array}$ & $\begin{array}{l}\text { Selection } \\
\text { of } \\
\text { controls }\end{array}$ & $\begin{array}{l}\text { Definition } \\
\text { of } \\
\text { controls }\end{array}$ & $\begin{array}{l}\text { Comparability } \\
\text { of both } \\
\text { groups }\end{array}$ & $\begin{array}{l}\text { Ascertainment } \\
\text { of diagnosis }\end{array}$ & $\begin{array}{l}\text { Same } \\
\text { ascertainment } \\
\text { method for both } \\
\text { groups }\end{array}$ & $\begin{array}{l}\text { Nonresponse } \\
\text { rate }\end{array}$ & $\begin{array}{l}\text { Total } \\
\text { scores }\end{array}$ \\
\hline $\begin{array}{l}\text { Chen G. } \\
2020 \text { [3] }\end{array}$ & $i s$ & $\overline{i n}$ & $\dot{\omega}$ & is & $\bar{\psi}$ & $\hat{\psi}$ & $\dot{\omega}$ & $\dot{\omega}$ & 8 \\
\hline $\begin{array}{l}\text { Chen R. } \\
2020 \text { [31] }\end{array}$ & $i$ & 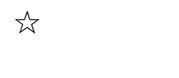 & $\dot{\omega}$ & is & $\dot{\omega}$ & $\hat{\Sigma}$ & $\dot{\omega}$ & $\dot{\omega}$ & 8 \\
\hline $\begin{array}{l}\text { Chi Y. } \\
2020 \text { [10] }\end{array}$ & 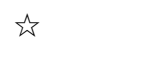 & $\hat{i n}$ & $\hat{i}$ & is & 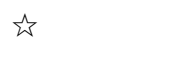 & is & $\dot{s}$ & $\hat{s}$ & 8 \\
\hline $\begin{array}{l}\text { Du R. } \\
2020 \text { [9] }\end{array}$ & $i$ & $i$ & 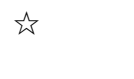 & $\hat{i n}$ & $\dot{\omega}$ & $\hat{i}$ & $\dot{\omega}$ & $\dot{\omega}$ & 8 \\
\hline $\begin{array}{l}\text { He R. } \\
2020 \text { [6] }\end{array}$ & $i$ & is & $i$ & $i$ & $\dot{\omega}$ & $\dot{\Sigma}$ & $\dot{\omega}$ & $i$ & 8 \\
\hline $\begin{array}{l}\text { Jiang M. } \\
2020 \text { [12] }\end{array}$ & $i$ & is & $i$ & $i$ & $\dot{\omega}$ & $\hat{\Sigma}$ & $\dot{\omega}$ & $i$ & 8 \\
\hline $\begin{array}{l}\text { Li S. } 2020 \\
{[24]}\end{array}$ & $i$ & $\hat{i n}$ & $i$ & $\dot{s}$ & 㑔糸 & $\sum$ & $\dot{s}$ & $\dot{s}$ & 9 \\
\hline $\begin{array}{l}\text { Liu Y. } \\
2020 \text { [32] }\end{array}$ & $i$ & $\hat{i n}$ & $i$ & $\hat{i n}$ & I & $\hat{\Sigma}$ & $\dot{\omega}$ & $\dot{s}$ & 7 \\
\hline $\begin{array}{l}\text { Ma J. } \\
2020 \text { [33] }\end{array}$ & 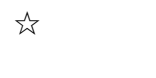 & $i$ & 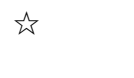 & $\hat{i n}$ & $\hat{i}$ & $\hat{n}$ & $\dot{\omega}$ & $\dot{\omega}$ & 9 \\
\hline $\begin{array}{l}\text { Pallotto } \\
\text { C. } 2020 \\
{[34]}\end{array}$ & 弥 & $\hat{s}$ & is & $\hat{\xi}$ & 论的 & 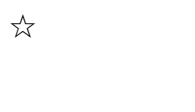 & $\dot{\xi}$ & 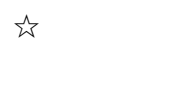 & 9 \\
\hline $\begin{array}{l}\text { Qin C. } \\
2020[4]\end{array}$ & $i s$ & $\hat{i s}$ & $i$ & is & $\dot{z}$ & $\hat{n}$ & $\dot{\omega}$ & is & 8 \\
\hline $\begin{array}{l}\text { Sophie H. } \\
2020 \text { [5] }\end{array}$ & $i$ & is & $\hat{\Sigma}$ & is & 访糸 & $\hat{i}$ & $\dot{s}$ & $\dot{s}$ & 9 \\
\hline $\begin{array}{l}\text { Sun D. } \\
2020 \text { [15] }\end{array}$ & is & $\hat{s}$ & $\dot{s}$ & is & $\dot{\xi}$ & $\hat{n}$ & $\dot{s}$ & $\dot{s}$ & 8 \\
\hline $\begin{array}{l}\text { Urra J.M. } \\
2020 \text { [35] }\end{array}$ & $i$ & 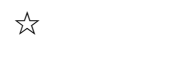 & $i$ & is & 访糸 & $\hat{i}$ & $\dot{\omega}$ & 弥 & 9 \\
\hline $\begin{array}{l}\text { Wan S. } \\
2020 \text { [13] }\end{array}$ & is & 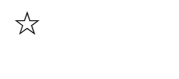 & $i$ & is & $\hat{i}$ & $\hat{i}$ & $\dot{\omega}$ & 弥 & 8 \\
\hline $\begin{array}{l}\text { Wang F. } \\
2020 \text { [18] }\end{array}$ & is & $i$ & $i$ & $i$ & 㑔访 & $\hat{\Sigma}$ & $\dot{\omega}$ & 访 & 9 \\
\hline $\begin{array}{l}\text { Zhang J. } \\
2020 \text { [19] }\end{array}$ & is & $i$ & $i$ & $i$ & $\hat{i}$ & $\hat{\Sigma}$ & $\dot{\omega}$ & 访 & 9 \\
\hline $\begin{array}{l}\text { Zhao Y. } \\
2020 \text { [7] }\end{array}$ & 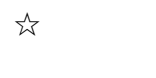 & $\hat{s}$ & $\dot{s}$ & is & 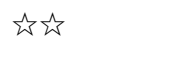 & $\hat{n}$ & $\dot{s}$ & $\dot{s}$ & 9 \\
\hline $\begin{array}{l}\text { Zheng Y. } \\
2020 \text { [36] }\end{array}$ & is & $\hat{s}$ & $\dot{s}$ & is & $\dot{\xi}$ & $\hat{n}$ & $\dot{s}$ & $\dot{s}$ & 8 \\
\hline $\begin{array}{l}\text { Zhou Y. } \\
2020 \text { [14] }\end{array}$ & is & is & $i$ & is & $\dot{\omega}$ & $\hat{\sim}$ & $\dot{\omega}$ & $i$ & 8 \\
\hline $\begin{array}{l}\text { Zhu Z. } \\
2020 \text { [16] }\end{array}$ & is & $\hat{i n}$ & $i$ & is & $\dot{s}$ & $\hat{n}$ & $\dot{\omega}$ & is & 8 \\
\hline
\end{tabular}

our meta-analysis results found that the decrease in $\mathrm{CD}^{+} \mathrm{T}, \mathrm{CD} 8+\mathrm{T}, \mathrm{CD} 4+\mathrm{T}, \mathrm{B}$ and NK cells was significant in severe cases, but Treg cells and the ratio of $\mathrm{CD}^{+} / \mathrm{CD}^{+} \mathrm{T}$ cells showed no significant difference.

The mechanism underlying the reduction of immune cell levels and COVID-19 severity remains to be determined. $\mathrm{CD}^{+} \mathrm{T}$ cells exert their effects mainly through two mechanisms, including cytolytic activity against target cells and cytokine secretion [16]. CD4 ${ }^{+}$ $\mathrm{T}$ cells are capable of activating the $\mathrm{CD}^{+} \mathrm{T}$ cell response to acute respiratory virus infection [11]. SARS-CoV-2 and associated autoimmune antibodies may contribute to the growth inhibition and apoptosis of immune cells $[6,17]$. 
a

b
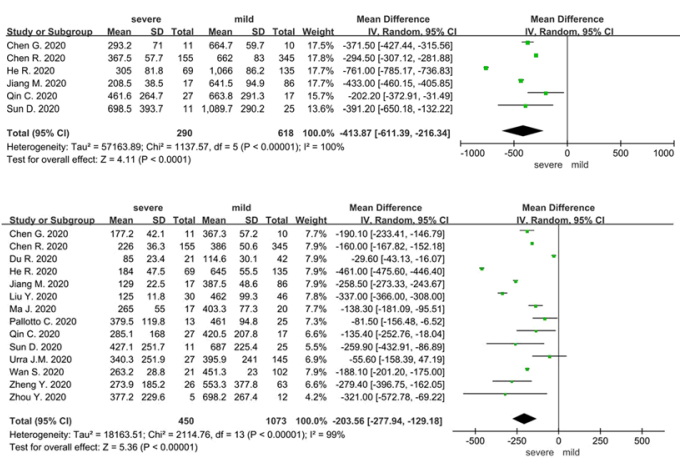

C

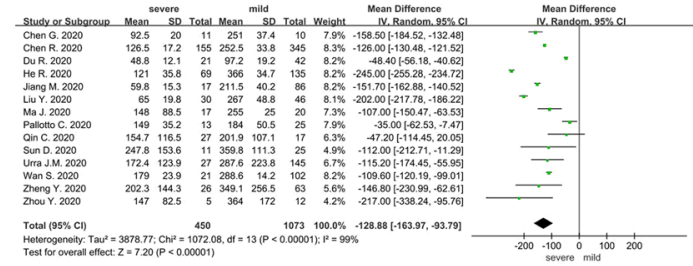

d

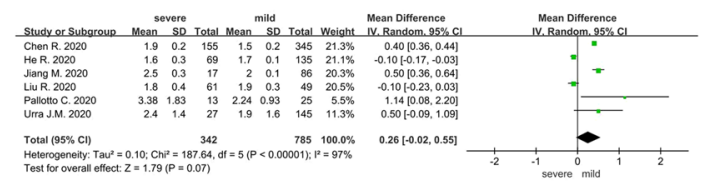

e

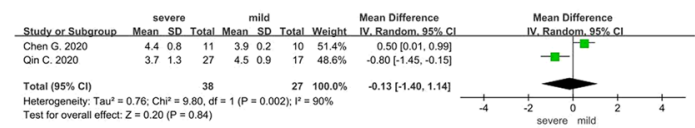

f

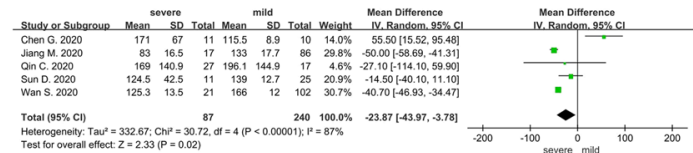

g

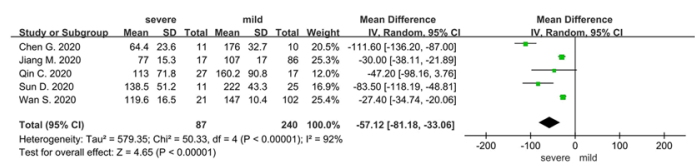

$\mathrm{h}$

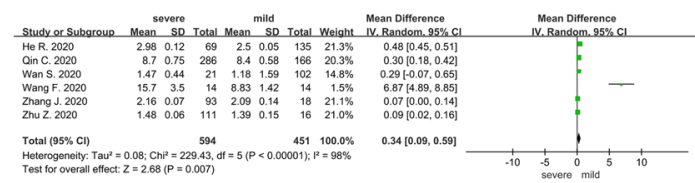

i

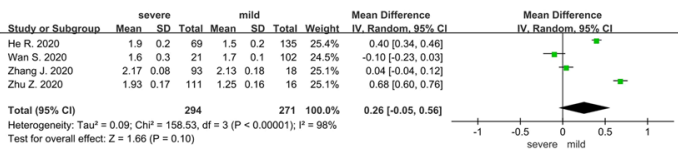

j

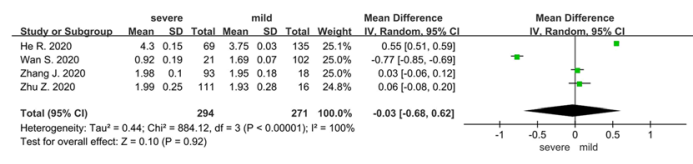

k

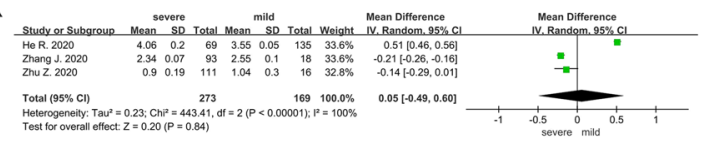

I

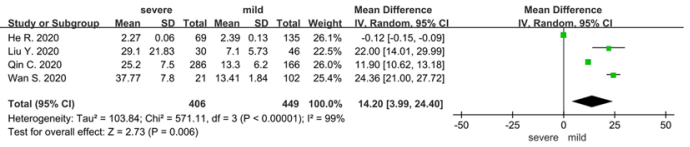

m

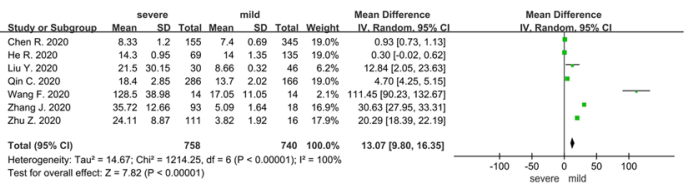

$\mathrm{n}$

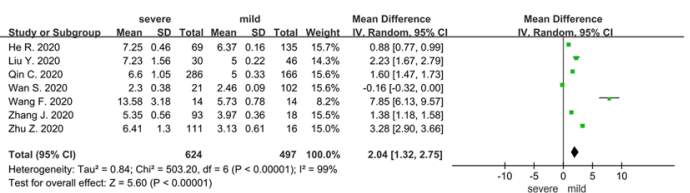

0

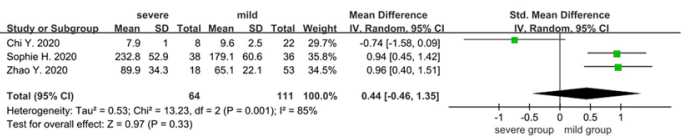

p

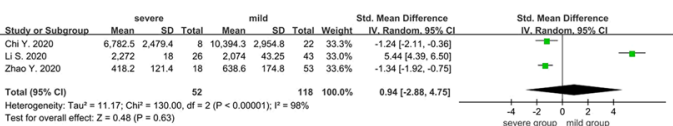

q

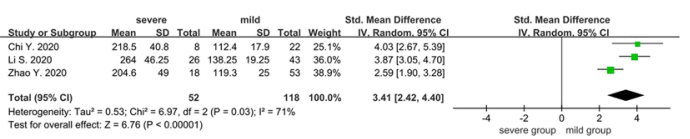

r

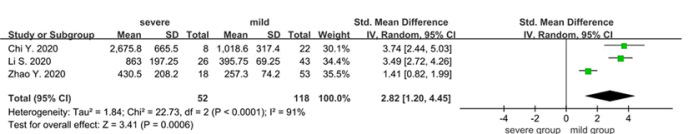

S

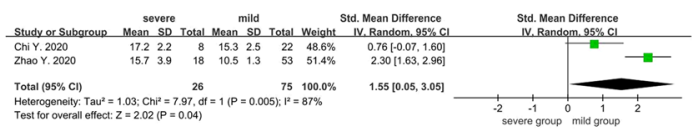

Fig. 2 a. CD3+ T cell. b. CD4+ T cell. c. CD8+ T cell. d. CD4+ / CD8+ ratio. e. Treg cell. f. B cell. g. NK cell. h. TNF-a. i. IFN-y. j. IL-2. k. IL-4. I I IL-5. $\mathbf{m}$. IL-6. n. IL-10. o. GM-CSF. p. RANTES. q. MCP-1. r. IP-10. 2 s. Eotaxin 

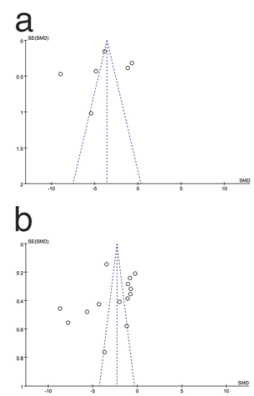

C

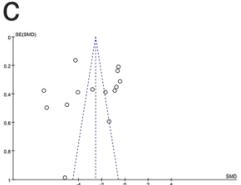

d

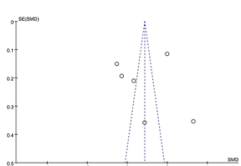

e

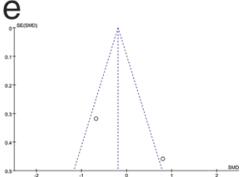

$f$

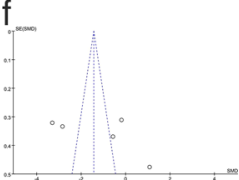

g

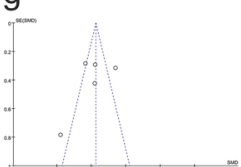

h
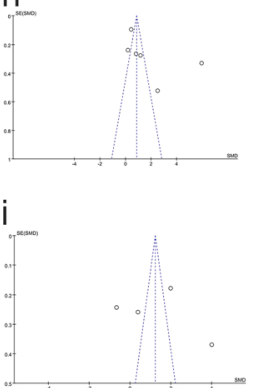

j

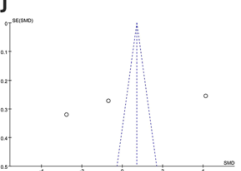

k

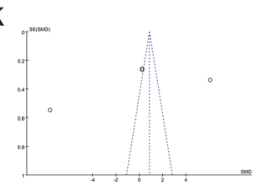

I

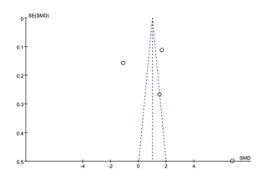

m

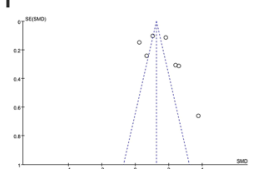

$\mathrm{n}$

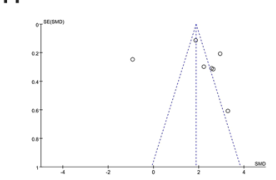

O

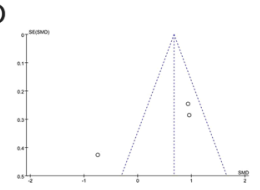

$\mathrm{p}$

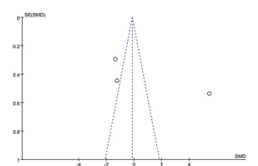

q

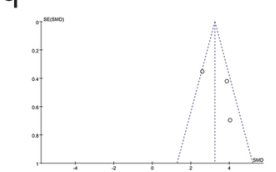

r

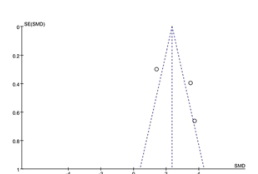

S

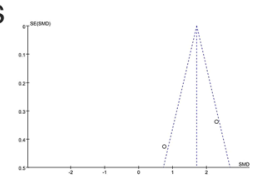

Fig. 3 a. CD3+ T cell. b. CD4+ T cell. c. CD8+ T cell. d. CD4+ / CD8+ ratio. e. Treg cell. f. B cell. g. NK cell. h. TNF-a. i. IFN-y. j. IL-2. k. IL-4. I. IL-5. m. IL-6. n. IL-10. o. GM-CSF. p. RANTES. q. MCP-1. r. IP-10.

s. Eotaxin

The cytokine variations of various studies are also inconsistent. Except for one study on IL-6 [6] and another study on TNF- $\alpha$, most of our included studies reported that IL- 6 and TNF- $\alpha$ levels were significantly higher in severe cases compared with mild cases $[4,16,18,19]$. Some of our included studies found no significant difference in the levels of IL-2, IL-4, IL-5, and IFN- $\gamma$, while almost an equivalent number of studies of each indicator found that they were significantly higher in severe cases. Synthesizing all the collected evidence, our meta-analysis results found that IL-5, IL-6, IL-10 and TNF- $\alpha$ levels were significantly higher in severe cases compared with mild cases. However, the levels of IL-2, IL-4, IFN- $\gamma$, Treg cells and $\mathrm{CD} 4^{+} / \mathrm{CD}^{+}$ratios showed no significant differences.

In severely infected individuals, SARS-CoV-2 could induce an excessive cytokine response, such as IL-6, IL-10, and TNF- $\alpha$ surge, known as cytokine storm. Cytokine storms may contribute to acute respiratory distress syndrome (ARDS) or multiple-organ dysfunction, resulting in physiological deterioration and death [20]. Cytokines such as IL-10, IL-6, and TNF- $\alpha$ are also involved in the decline of T cell counts. IL-6 contributes to host defense by stimulating acute phase responses [21]. TNF- $\alpha$ is a pro-inflammatory cytokine that can promote $\mathrm{T}$ cell apoptosis [22]. Patients requiring ICU admission have significantly higher levels of IL-6, IL-10, and TNF- $\alpha$. Further, the levels of IL-6, IL-10, and TNF- $\alpha$ inversely correlate with $\mathrm{CD}^{+}$and $\mathrm{CD}^{+}{ }^{+}$cell counts [23]. This fact is strengthened by our meta-analysis results.

SARS-CoV-2 infection is a potent inducer of proinflammatory chemokines that are potentially involved in the defense against viral infection [10]. Some studies have reported higher concentrations of GM-CSF [5], IP10 [5, 10, 24], MCP-1 [10, 24], eotaxin [7] and RANTES [24] between severe cases and mild cases. However, other studies have not revealed significant differences in the concentrations of GM-CSF [7, 10], IP-10 [7], RANTES [10], MCP-1 [7], and eotaxin [10] . Synthesizing all the collected evidence, our meta-analysis results found that MCP-1, IP-10 and eotaxin levels were significantly higher in severe cases compared with mild cases. However, levels of GM-CSF and RANTES showed no significant differences. Binding to the chemokine receptor 3, IP-10 activates and recruits leucocytes, including $\mathrm{T}$ cells and monocytes [25]. MCP-1-mediated migration of monocytes from the blood stream through the vascular endothelium is essential for routine immune surveillance in tissues in response to inflammation [26]. 
Abnormally elevated MCP-1, IP-10 and eotaxin levels may help to determine the severity of SARS-CoV-2 infections and serve as prognostic markers for disease progression.

Cytokines and chemokines play a key role in the pathogenesis of ARDS. After SARS-CoV-2 infection, vascular endothelial cells become dysfunctional and IL-6, TNF-a, and MCP-1 levels are elevated, leading to COVID-19-associated vascular inflammation and coagulopathy, particularly endotheliitis in the lungs, heart and kidney $[27,28]$. TNF-a is central in the pathogenesis of inflammation and triggers the release of many inflammatory mediators including IL-1, IL-6, IL-8, and GM-CSF [29]. TNF-a can also disintegrate the endothelial and epithelial cytoskeleton, resulting in alveolar-capillary barrier disruption, vascular leakage and alveolar edema, which in turn leads to hypoxia in the body [30].

\section{Limitations}

Several limitations of our study should be considered. Firstly, the number of studies and participants was not large enough for publication bias analysis of most indicators. Secondly, the majority of the included studies in this meta-analysis were retrospectives. Thirdly, the overall generalizability of the meta-analysis results should be interpreted with caution as most of the included studies were conducted in China due to limitations in geographic distribution and ethnic diversity. It would be better to include more studies with a broad geographic scope to gain a more comprehensive understanding of the immunological features of COVID-19 patients.

\section{Conclusions}

Our synthesized results revealed significantly lower levels of immune cells in $\mathrm{CD}^{+} \mathrm{T}, \mathrm{CD}^{+}{ }^{+} \mathrm{T}, \mathrm{CD} 8^{+} \mathrm{T}, \mathrm{B}$ and NK cells, higher levels of cytokines (TNF- $\alpha$, IL-5, IL-6 and IL-10) and higher levels of chemokines (MCP1, IP-10 and eotaxin) in severe cases compared with mild cases of COVID-19. However, there was no significant difference in levels of Treg cell, the ratio of $\mathrm{CD} 4^{+} / \mathrm{CD}^{+}$ T cell, IL-2, IL-4, IFN- $\gamma$, GM-CSF and RANTES. Measurement of immune cells and cytokines may help identify immune markers of COVID-19 severity and contribute to the development of immunologic therapies and vaccines.

\footnotetext{
Abbreviations

COVID-19: Coronavirus disease 2019; SARS-CoV-2: Severe acute respiratory syndrome coronavirus 2; MD: Mean difference; IQR: Interquartile range; IL2: Interleukin-2; IL-4: Interleukin-4; IL-5: Interleukin-5; IL-6: Interleukin-6; IL10: Interleukin-10; TNF-a: Tumor necrosis factor alpha; IFN- $\gamma$ : Interferon gamma; NK cell: Natural killer cell; Cl: Confidence interval; NOS: Newcastleottawa scale; ARDS: Acute respiratory distress syndrome; SD: Standard deviation; GM-CSF: Granulocyte-macrophage colony-stimulating factor; RANTES (CCL5): Regulated upon activation, normal T-cell expressed and secreted; IP-10 (CXCL10): IFN-y Inducible protein-10; MCP-1 (CCL2): Monocyte chemoattractant protein-1
}

\section{Supplementary Information}

The online version contains supplementary material available at https://doi. org/10.1186/s12879-021-06457-1.

\section{Additional file 1.}

\section{Acknowledgments}

We thank Yunsheng, Fang, Ph.D (University of California, Los Angeles, California, UCLA) for revision of the manuscript.

\section{Authors' contributions}

Conception: ZZ, HJJ. Literature search: ZZ, HJJ. Selection of studies: ZX, ZC. Full texts search: ZZ, LS. Data extraction: GC. Data synthesis and analysis: ZZ, AG. Data interpretation: CL. Manuscript drafting: ZZ, HJJ. Manuscript editing and revision: LS, HJH. Manuscript final version approval: ZZ, QH, HJH. Guarantor of the review: HJJ, HJH.

\section{Funding}

The study is supported in part by a research grant from the Fundamental Research Funds for the Central Universities (project No.2016YXMS111), and 2017 Teaching Research Project of Huazhong University of Science and Technology (project No.105).

\section{Availability of data and materials}

The datasets used and/or analysed during the current study are available from the corresponding author on reasonable request.

\section{Declarations}

Ethics approval and consent to participate

Not applicable.

\section{Consent for publication}

Not applicable.

\section{Competing interests}

The authors declare that they have no competing interests.

\section{Author details}

${ }^{1}$ Department of Gastroenterology, Tongji Hospital, Tongji Medical College, Huazhong University of Science and Technology, Wuhan, China.

¿Department of Molecular and Medical Pharmacology, David Geffen School of Medicine, University of California, Los Angeles (UCLA), Los Angeles, USA.

${ }^{3}$ Department of Pediatrics, Tongji Hospital, Tongji Medical College, Huazhong University of Science and Technology, Wuhan, China. ${ }^{4}$ Department of Oncology, Tongji Hospital, Tongji Medical College, Huazhong University of Science and Technology, Wuhan, China. ${ }^{5}$ Department of Oncology, Huang Gang Central Hospital, Huanggang, China. ${ }^{6}$ Department of Endocrinology, Huang Gang Central Hospital, Huanggang, China. ${ }^{7}$ Department of Hematology, Tongji Hospital, Tongji Medical College, Huazhong University of Science and Technology, Wuhan 430030, China.

Received: 26 June 2020 Accepted: 23 July 2021

Published online: 03 August 2021

\section{References}

1. Huang C, Wang Y, Li X, Ren L, Zhao J, Hu Y, et al. Clinical features of patients infected with 2019 novel coronavirus in Wuhan. China Lancet. 2020;395(10223):497-506. https://doi.org/10.1016/S0140-6736(20)30183-5.

2. World Health Organization. Coronavirus disease (COVID-19). Weekly Operational Update [accessed 9 September 2020]. Available from: https:// www.who.int/docs/default-source/coronaviruse/weekly-updates/wou-9september-2020-cleared-14092020.pdf?sfvrsn=68120013_2.

3. Chen G, Wu D, Guo W, Cao Y, Huang D, Wang H, et al. Clinical and immunological features of severe and moderate coronavirus disease 2019. J Clin Invest. 2020;130(5):2620-9. https://doi.org/10.1172/JCl137244.

4. Qin C, Zhou L, Hu Z, Zhang S, Yang S, Tao Y, et al. Dysregulation of immune response in patients with COVID-19 in Wuhan. China Clin Infect Dis. 2020;71(15):762-8. https://doi.org/10.1093/cid/ciaa248. 
5. Hue S, Beldi-Ferchiou A, Bendib I, Surenaud M, Fourati S, Frapard T, et al. Uncontrolled innate and impaired adaptive immune responses in patients with COVID-19 ARDS. Am J Respir Crit Care Med. 2020;202(11):1509-19. https://doi.org/10.1164/rccm.202005-18850C.

6. He R, Lu Z, Zhang L, Fan T, Xiong R, Shen X, et al. The clinical course and its correlated immune status in COVID-19 pneumonia. J Clin Virol. 2020;127: 104361. https://doi.org/10.1016/j.jcv.2020.104361.

7. Zhao Y, Qin L, Zhang P, Li K, Liang L, Sun J, et al. Longitudinal COVID-19 profiling associates IL-1RA and IL-10 with disease severity and RANTES with mild disease. JCI Insight. 2020;5(13). https://doi.org/10.1172/jci.insight.13 9834.

8. Hozo SP, Djulbegovic B, Hozo I. Estimating the mean and variance from the median, range, and the size of a sample. BMC Med Res Methodol. 2005;5(1): 13. https://doi.org/10.1186/1471-2288-5-13.

9. Du R-H, Liang L-R, Yang C-Q, Wang W, Cao T-Z, Li M, et al. Predictors of mortality for patients with COVID-19 pneumonia caused by SARS-CoV-2: a prospective cohort study. Eur Respir J. 2020;55(5):2000524. https://doi.org/1 0.1183/13993003.00524-2020.

10. Chi Y, Ge Y, Wu B, Zhang W, Wu T, Wen T, et al. Serum cytokine and chemokine profile in relation to the severity of coronavirus disease 2019 in China. J Infect Dis. 2020;222(5):746-54. https://doi.org/10.1093/infdis/jiaa363.

11. Rogers MC, Lamens KD, Shafagati N, Johnson M, Oury TD, Joyce S, et al. CD4+ regulatory $T$ cells exert differential functions during early and late stages of the immune response to respiratory viruses. J Immunol. 2018; 201(4):1253-66. https://doi.org/10.4049/jimmunol.1800096.

12. Jiang M, Guo Y, Luo Q, Huang Z, Zhao R, Liu S, et al. T cell subset counts in peripheral blood can be used as discriminatory biomarkers for diagnosis and severity prediction of COVID-19. J Infect Dis. 2020;222(2):198-202. https://doi.org/10.1093/infdis/jiaa252.

13. Wan S, Yi Q, Fan S, Lv J, Zhang X, Guo L, et al. Relationships among lymphocyte subsets, cytokines, and the pulmonary inflammation index in coronavirus (COVID-19) infected patients. Br J Haematol. 2020;189(3):428-37. https://doi.org/10.1111/bjh.16659.

14. Zhou Y, Zhang Z, Tian J, Xiong S. Risk factors associated with disease progression in a cohort of patients infected with the 2019 novel coronavirus. Ann Palliat Med. 2020;9:428-36. https://doi.org/10.21037/apm.2 020.03.26.

15. Sun D-W, Zhang D, Tian R-H, Li Y, Wang Y-S, Cao J, et al. The underlying changes and predicting role of peripheral blood inflammatory cells in severe COVID-19 patients: a sentinel? Clin Chim Acta. 2020;508:122-9. https://doi.org/10.1016/j.cca.2020.05.027.

16. Zhu Z, Cai T, Fan L, Lou K, Hua X, Huang Z, et al. Clinical value of immuneinflammatory parameters to assess the severity of coronavirus disease 2019. Int J Infect Dis. 2020;95:332-9. https://doi.org/10.1016/j.jijid.2020.04.041

17. Yang M, Li CK, Li K, Hon KLE, Ng MHL, Chan PK, et al. Hematological findings in SARS patients and possible mechanisms (review). Int J Mol Med. 2004;14(2):311-5.

18. Wang F, Yang Y, Dong K, Yan Y, Zhang S, Ren H, et al. Clinical characteristics of 28 patients with diabetes and COVID-19 in Wuhan. CHINA Endocr Pract. 2020;26(6):668-74. https://doi.org/10.4158/EP-2020-0108.

19. Zhang J, Yu M, Tong S, Liu L-Y, Tang L-V. Predictive factors for disease progression in hospitalized patients with coronavirus disease 2019 in Wuhan, China. J Clin Virol. 2020;127:104392. https://doi.org/10.1016/j.jcv.202 0.104392 .

20. Moore JB, June $\mathrm{CH}$. Cytokine release syndrome in severe COVID-19. Science. 2020;368(6490):473-4. https://doi.org/10.1126/science.abb8925.

21. Jones SA, Jenkins BJ. Recent insights into targeting the IL-6 cytokine family in inflammatory diseases and cancer. Nat Rev Immunol. 2018;18(12):773-89. https://doi.org/10.1038/s41577-018-0066-7.

22. Gupta S, Bi R, Kim C, Chiplunkar S, Yel L, Gollapudi S. Role of NF-kappaB signaling pathway in increased tumor necrosis factor-alpha-induced apoptosis of lymphocytes in aged humans. Cell Death Differ. 2005;12(2): 177-83. https://doi.org/10.1038/sj.cdd.4401557

23. Diao B, Wang C, Tan Y, Chen X, Liu Y, Ning L, et al. Reduction and functional exhaustion of T cells in patients with coronavirus disease 2019 (COVID-19). Front Immunol. 2020;11:827. https://doi.org/10.3389/fimmu.202 0.00827 .

24. Li S, Jiang L, Li X, Lin F, Wang Y, Li B, et al. Clinical and pathological investigation of patients with severe COVID-19. JCI Insight. 2020;5(12). https://doi.org/10.1172/jci.insight.138070.
25. Costela-Ruiz VJ, Illescas-Montes R, Puerta-Puerta JM, Ruiz C, MelguizoRodríguez L. SARS-CoV-2 infection: the role of cytokines in COVID-19 disease. Cytokine Growth Factor Rev. 2020;54:62-75. https://doi.org/10.1016/ j.cytogfr.2020.06.001.

26. Shi C, Pamer EG. Monocyte recruitment during infection and inflammation. Nat Rev Immunol. 2011;11(11):762-74. https://doi.org/10.1038/nri3070.

27. Zhang J, Tecson KM, McCullough PA. Endothelial dysfunction contributes to COVID-19-associated vascular inflammation and coagulopathy. Rev Cardiovasc Med. 2020;21:315-9. https://doi.org/10.31083/j.rcm.2020.03.126.

28. Hu B, Huang S, Yin L. The cytokine storm and COVID-19. J Med Virol. 2021; 93(1):250-6. https://doi.org/10.1002/jmv.26232

29. Szatmáry Z. Tumor necrosis factor-alpha: molecular-biological aspects minireview. Neoplasma. 1999;46(5):257-66. 10665840.

30. Eisenhut M, Shin J. Pathways in the pathophysiology of coronavirus 19 lung disease accessible to prevention and treatment. Front Physiol. 2020;11:872. https://doi.org/10.3389/fphys.2020.00872.

31. Chen $R$, Sang L, Jiang M, Yang Z, Jia N, Fu W, et al. Longitudinal hematologic and immunologic variations associated with the progression of COVID-19 patients in China. J Allergy Clin Immunol. 2020;146(1):89-100. https://doi.org/10.1016/j.jaci.2020.05.003.

32. Liu Y, Liao W, Wan L, Xiang T, Zhang W. Correlation between relative nasopharyngeal virus RNA load and lymphocyte count disease severity in patients with COVID-19. Viral Immunol. 2020;34(5):330-5. https://doi.org/10.1 089/vim.2020.0062.

33. Ma J, Yin J, Qian Y, Wu Y. Clinical characteristics and prognosis in cancer patients with COVID-19: a single center's retrospective study. The Journal of infection. 2020;81(2):318-56. https://doi.org/10.1016/j.jinf.2020.04.006.

34. Pallotto C, Suardi LR, Esperti S, Tarquini R, Grifoni E, Meini S, et al. Increased CD4/CD8 ratio as a risk factor for critical illness in coronavirus disease 2019 (COVID-19): a retrospective multicentre study. Infectious Diseases. 2020;52(9): 675-7. https://doi.org/10.1080/23744235.2020.1778178.

35. Urra JM, Cabrera CM, Porras L, Ródenas I. Selective CD8 cell reduction by SARS-CoV-2 is associated with a worse prognosis and systemic inflammation in COVID-19 patients. Clin Immunol. 2020;217:108486. https:// doi.org/10.1016/j.clim.2020.108486.

36. Zheng $Y, X u H$, Yang M, Zeng Y, Chen H, Liu R, et al. Epidemiological characteristics and clinical features of 32 critical and 67 noncritical cases of COVID-19 in Chengdu. J Clin Virol. 2020;127:104366. https://doi.org/10.1016/ j.jcv.2020.104366.

\section{Publisher's Note}

Springer Nature remains neutral with regard to jurisdictional claims in published maps and institutional affiliations.

Ready to submit your research? Choose BMC and benefit from:

- fast, convenient online submission

- thorough peer review by experienced researchers in your field

- rapid publication on acceptance

- support for research data, including large and complex data types

- gold Open Access which fosters wider collaboration and increased citations

- maximum visibility for your research: over $100 \mathrm{M}$ website views per year

At BMC, research is always in progress.

Learn more biomedcentral.com/submissions 